\title{
The sequential feeding of growing chickens
}

\author{
By R. M. GOUS AND J. J. DU PREEZ \\ Department of Animal Science and Poultry Science, \\ University of Natal, Pietermaritzburg 3200, South Africa
}

(Received ${ }_{14}$ October 1974 - Accepted 13 December 1974)

\begin{abstract}
I. Male chickens, I week old, were fed alternately for 6 or $12 \mathrm{~h}$ periods with diets complementary in their amino acid composition. The isonitrogenous, isoenergetic diets were based on fish meal or sunflower meal as the sole source of protein, or fish meal-sunflower meal (40:6o, $\mathrm{w} / \mathrm{w})$; each diet contained $\mathrm{I} 20 \mathrm{~g}$ crude protein $/ \mathrm{kg}$. Other groups of chickens were given these diets ad lib.

2. Net protein utilization (NPU) values obtained after a $\mathrm{I}$-week experimental period indicated that sequential feeding for both 6 and $12 \mathrm{~h}$ resulted in significantly improved responses compared with chickens given the same diets $a d l i b$. These results suggested that the two protein sources, although provided at separate times, could complement each other.

3. In certain treatments there was a 6 or $12 \mathrm{~h}$ fasting period between feeding periods to reduce the effect of nutrients from the previous period.

4. For alternate feeding and fasting periods of $6 \mathrm{~h}$ with the combined diet, food intake and gain in body-weight were both significantly reduced compared with the corresponding values for the combined diet fed $a d l i b$. The NPU value was virtually the same for both treatments. For $12 \mathrm{~h}$ periods of alternate feeding and fasting the gain in body-weight was only just significantly lower than that for the control group (combined diet fed ad lib.), but the NPU value was highly significantly better than that for the control group.

5. For the treatments which included 6 and $12 \mathrm{~h}$ fasting periods between the two singleprotein diets, the food intake and gain in body-weight were significantly lower compared with the treatment groups given alternate feeding and fasting periods of either 6 or $12 \mathrm{~h}$ with the combined diet. The NPU values for the two groups given $12 \mathrm{~h}$ alternate feeding and fasting periods differed significantly, whereas the NPU values for the two groups given $6 \mathrm{~h}$ feeding and fasting periods were the same.
\end{abstract}

Controversy exists with regard to the ability of a growing chicken to make use of amino acids when these are fed separately from the rest of the diet. Geiger (1947), Schaeffer \& Geiger (1947) and Henderson \& Harris (1949) showed that amino acid supplements fed several hours after the remaining dietary ingredients had been consumed were not utilized efficiently by young rats. Studies by Yang, Clark \& Vail (1961), Yang, Steinhauer \& Masterson (1963) and Yang, Tilton \& Ryland (I968) have shown that a lysine supplement fed separately from a lysine-deficient diet is as efficiently utilized by rats as when it is fed together with the same diet. These results could not be duplicated for tryptophan, and it was concluded that this was the result of a relatively rapid turnover of tryptophan compared with lysine in the rat.

Fisher (I967) states that the young, growing animal requires all essential amino acids to be present together in its diet, but the adult animal can make use of individual amino acids even if all other essential amino acids are absent. This simultaneous need for all essential amino acids by the young, growing animal has been termed an 'aggregate' amino acid requirement in contrast to a 'particulate' amino acid requirement for the adult animal.

Several experiments have been done at this University using chickens to determine 
Table $\mathrm{i}$. Composition ( $g$ ) of the diets fed to growing chickens

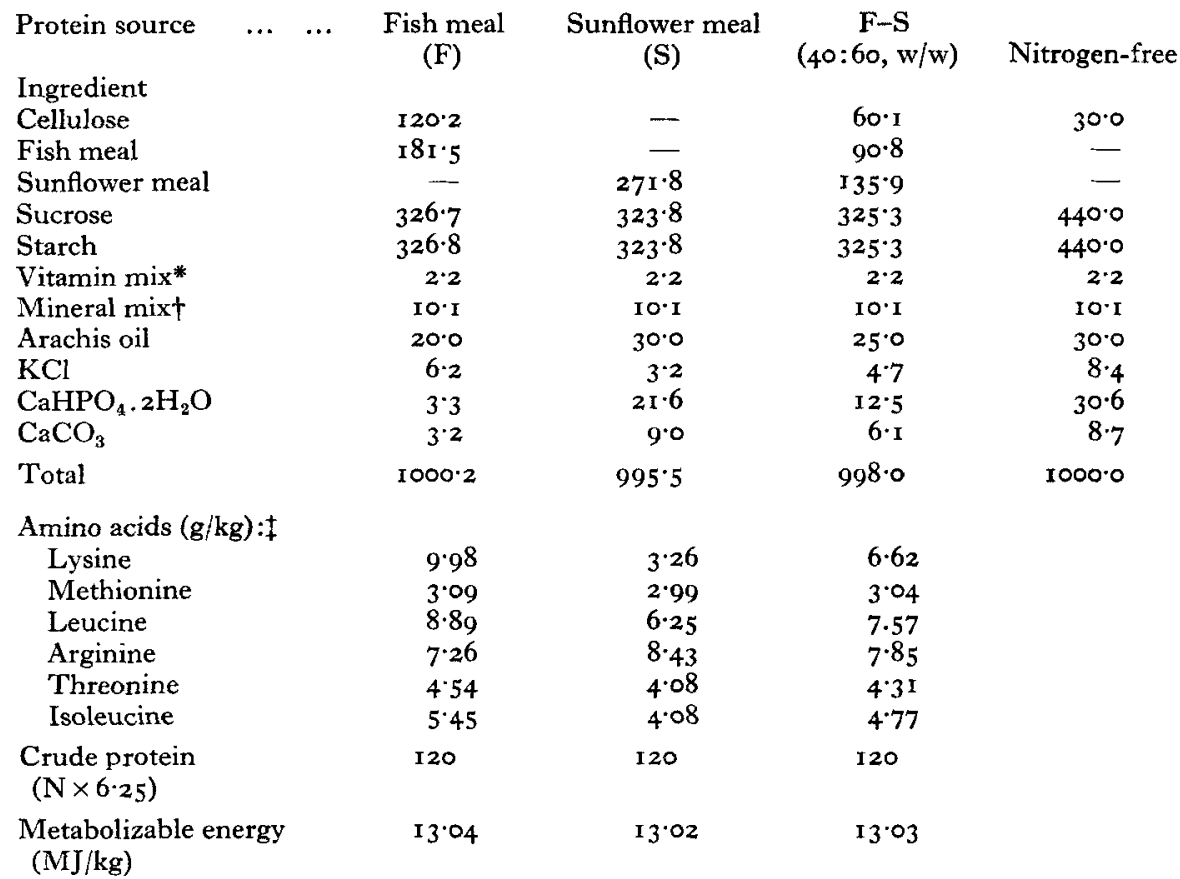

* Vitamin premix consisted of $(\mathrm{mg} / \mathrm{g})$ : thiamin 35 , riboflavin 23 , pyridoxine 8 , biotin 0.8 , pteroylmonoglutamic acid 5.7, menaphthone 7, cyanocobalamin 0.03 , nicotinic acid 213 , ascorbic acid 354, retinol (1982 $\mu \mathrm{g} / \mathrm{g}) 212 \cdot 7$, cholecalciferol $(2000 \mu \mathrm{g} / \mathrm{g}) 10 \cdot 2, \alpha$-tocopherol $(250 \mathrm{mg} / \mathrm{g}) 6$, maize starch 95 . † Mineral premix consisted of $(\mathrm{g} / \mathrm{kg}): \mathrm{KH}_{2} \mathrm{PO}_{4} 479, \mathrm{NaCl} 365$, ferric citrate $23, \mathrm{MgSO}_{4}$ If $_{4}$, $\mathrm{MnSO}_{4} \cdot \mathrm{H}_{2} \mathrm{O} 9, \mathrm{KI} 0_{4} 6, \mathrm{CuSO}_{4} 0.58, \mathrm{ZnCO}_{3} 9, \mathrm{Na}_{2} \mathrm{MoO}_{4} \cdot \mathrm{H}_{2} \mathrm{O} 0_{4} \cdot 46$.

I Determined using an amino acid analyser (Model I20 B; Beckman Instruments Inc., Fullerton, California, USA) by the Department of Biochemistry, University of Natal.

the most suitable fish meal: sunflower meal ratio for their diets (Saunders, 1974). The experiment reported in this paper was designed to determine the effect on the efficiency of protein utilization when isoenergetic, isonitrogenous diets containing fish meal $(\mathrm{F})$ or sunflower meal (S) were fed alternately to chickens. In addition, for certain treatments there were fasting periods each day to reduce the effects of nutrients from the previous feeding period.

\section{EXPERIMENTAL PROCEDURE}

The chickens used in this experiment were I-week-old White Leghorn $\times$ Black Australorp males. These cockerels were housed in four five-tier, electrically heated brooders consisting of four compartments/tier. Five chickens were housed in each compartment. The brooder room was fan-ventilated and maintained at approximately $25^{\circ}$ for the experimental period. At I week of age the weight of each chicken was recorded. The 400 chickens closest to the mean weight were selected from the 700 chickens available, and were allocated completely at random to the eighty compartments. 
The diets contained $\mathrm{F}$ or $\mathrm{S}$ as the sole source of protein or $\mathrm{F}-\mathrm{S}(40: 60, \mathrm{w} / \mathrm{w})$. These three diets were isonitrogenous and isoenergetic. A nitrogen-free diet was included in the experiment for the determination of endogenous $\mathrm{N}$ for the net protein utilization (NPU) calculations. The composition of the four diets is given in Table $I$.

The ten different dietary treatments and feeding regimens used in the experiment were as follows:

(I) combined diet (F-S) fed ad lib.;

(2) F diet fed ad lib.;

(3) S diet fed ad lib.;

(4) F and S diets fed alternately every $6 \mathrm{~h}$;

(5) $\mathrm{F}$ and $\mathrm{S}$ diets fed alternately every $\mathrm{I} 2 \mathrm{~h}$;

(6) $\mathrm{F}$ diet for $6 \mathrm{~h}$, followed by $6 \mathrm{~h}$ fast, then $\mathrm{S}$ diet for $6 \mathrm{~h}$ followed by $6 \mathrm{~h}$ fast;

(7) $\mathrm{F}$ diet for $12 \mathrm{~h}$, followed by $\mathrm{I} 2 \mathrm{~h}$ fast, then $\mathrm{S}$ diet for $12 \mathrm{~h}$ followed by $\mathrm{I} 2 \mathrm{~h}$ fast;

(8) F-S diet for $6 \mathrm{~h}$, alternating with fasting periods of $6 \mathrm{~h}$;

(9) F-S diet for $12 \mathrm{~h}$, alternating with fasting periods of $12 \mathrm{~h}$;

(Iо) N-free diet fed ad lib.

Each of the ten treatments was replicated eight times using five chickens for each replication.

The experiment started at I3.00 hours when all feeding troughs were opened simultaneously. The $\mathrm{F}$ diet was fed first in treatments involving the feeding of the two single-protein diets (treatments $4,5,6,7$ ). Changes of feeding troughs, where necessary, took place at $6 \mathrm{~h}$ intervals for $6 \mathrm{~d}$. At o1.0o hours on the $7^{\text {th }}$ day all feeding and water troughs were closed. After $8 \mathrm{~h}$ the weight of each chicken was recorded, just before they were killed using chloroform anaesthesia. Food consumption for each group was determined. Individual carcass moisture contents were obtained by determining the loss in body-weight during a Io d period in a forced-draught oven operated at $95^{\circ}$.

The $\mathrm{N}$ content of each carcass was estimated from the equation: $y=\mathrm{I} 2 \mathrm{I} \cdot 6+33 \cdot 1 x$, where $y$ is body $\mathrm{N}(\mathrm{mg}$ ) and $x$ is body water content (g) (Wessels, I967); this equation had been determined for the breed of chicken used in this experiment, at 2 weeks of age. NPU values were calculated using the formula of Bender \& Doell (r957).

\section{RESULTS}

Chickens receiving the diet containing both $\mathrm{F}$ and $\mathrm{S}$ as protein sources (treatment $\mathrm{I}$ ) had a significantly higher food consumption, gain in body-weight and NPU (as indicated in Table 2) than chickens fed on diets containing $F$ and $S$ as single sources of protein (treatments 2 and 3 ).

The over-all food intakes for chickens given treatments $\mathrm{I}, 4$ and 5 ( $\mathrm{F}+\mathrm{S}$ ad lib., $\mathrm{F}$ and $\mathrm{S}$ alternately for $6 \mathrm{~h}$ periods, $\mathrm{F}$ and $\mathrm{S}$ alternately for $\mathrm{I} 2 \mathrm{~h}$ periods respectively) were similar. The latter two groups of chickens also ate very similar amounts of the $\mathrm{F}$ and $\mathrm{S}$ diets. The apparent preference of chickens for the $\mathrm{F}$ diet with treatment 5, was probably the result of the longer feeding period for this diet (the experiment ended at or .00 hours, eliminating a $\mathrm{I} 2 \mathrm{~h}$ feeding period for the $\mathrm{S}$ diet). 
Table 2. Mean food intake and mean gain in body-weight ( $g /$ chicken per $7 d)$, and net protein utilization (NPU) for chickens fed diets* containing (I) fish meal $(F)$ or (2) sunflower meal $(S)$ or (3) $F-S(40: 60, w / w)$ as the source of protein, for a $7 d$ period

(There were five chickens/treatment; each treatment was replicated eight times)

\begin{tabular}{cccc} 
Treatment & \multicolumn{3}{c}{ Food intake } \\
no.* & F diet & S diet & F-S diet \\
I & - & - & 104 \\
2 & 92 & - & - \\
3 & - & 75 & - \\
4 & 50 & 49 & - \\
5 & 53 & 47 & - \\
6 & 46 & 38 & - \\
7 & 39 & 29 & 90 \\
8 & - & - & 88 \\
9 & - & - & \\
Least significant difference $(P>0.05)$ & $(P>0.01)$
\end{tabular}

SE of difference between treatment means

$\begin{array}{ccc}\begin{array}{c}\text { Total food } \\ \text { intake }\end{array} & \begin{array}{c}\text { Gain in } \\ \text { body-weight }\end{array} & \text { NPU } \\ \text { ro4 } & 42 & 0.70 \\ 92 & 31 & 0.64 \\ 75 & 18 & 0.56 \\ 99 & 4 \mathrm{I} & 0.68 \\ 100 & 37 & 0.66 \\ 84 & 29 & 0.69 \\ 68 & 25 & 0.75 \\ 90 & 35 & 0.71 \\ 88 & 39 & 0.80 \\ 6 & 3 & 0.04 \\ 8 & 4 & 0.05 \\ 3.00 & \mathrm{I} .66 & 0.018\end{array}$

* For details of diets and treatments, see Table $\mathrm{I}$ and $\mathrm{p}$. I I5.

The very similar results obtained for treatments $I$ and 4 indicated that the two protein sources ( $\mathrm{F}$ and $\mathrm{S}$ ) could still complement each other when fed separately for successive periods of $6 \mathrm{~h}$ each. Increasing the feeding periods for the two diets to $12 \mathrm{~h}$ each (treatment 5 ) resulted in a reduced body-weight gain and decreased NPU, indicating that the diets failed to some extent in complementing each other. This sequential feeding, however, still gave superior results to those obtained when the $\mathrm{F}$ and $\mathrm{S}$ diets were fed separately, ad lib. (treatments 2 and 3 ).

When the combined $(\mathrm{F}-\mathrm{S})$ diet was fed for $6 \mathrm{~h}$ periods alternating with $6 \mathrm{~h}$ fasting periods (treatment 8 ), food intake and gain in body-weight were both significantly lower than those for treatment I (F-S, ad lib.). The NPU value was virtually the same for both treatments. When the combined diet was fed for $12 \mathrm{~h}$ periods alternating with $12 \mathrm{~h}$ fasting periods (treatment 9), the gain in body-weight was only just significantly lower than that for the control group (treatment $I$ ), although the NPU value was highly significantly $(P<0.00 \mathrm{r})$ greater than that for the control group.

Treatment groups 6 and 7 were fasted for 6 and $12 \mathrm{~h}$ between the 6 and $12 \mathrm{~h}$ feeding periods respectively to prevent any mixing of the two complementary diets in the alimentary tract. Results for treatments 6 and 7 indicated significantly lower food intakes and gains in body-weight than those for treatment groups 8 and 9 respectively ( $\mathrm{F}-\mathrm{S}$ diet fed for 6 and $\mathrm{i} 2 \mathrm{~h}$, alternating with 6 and $12 \mathrm{~h}$ fasting respectively). The NPU value for treatment group 6 was similar to that for treatment group 8 , although treatment group 7 had a significantly lower NPU value than treatment group 9 $(P<0.05)$. Nevertheless the NPU values for treatment groups 6 and 7 were both significantly higher than those for either $\mathrm{F}$ or $\mathrm{S}$ fed $a d l i b$. (treatments 2 and 3 ). 


\section{DISCUSSION}

The results obtained with treatment I confirm the finding (Saunders, I974) that $\mathrm{F}$ and $\mathrm{S}$ complement each other in providing a balanced amino acid mixture for growing chickens. The use of $\mathrm{F}$ or $\mathrm{S}$ as the only sources of protein (treatments 2 and 3) resulted in significant decreases in over-all food intake, body-weight gains and NPU values; the $\mathrm{S}$ diet was the poorest-quality diet. The alternate feeding of the $\mathrm{F}$ and $\mathrm{S}$ diets for periods of $6 \mathrm{~h}$ each (treatment 4 ) gave results very similar to those obtained with the combined diet (F-S) (treatment $\mathrm{I}$ ), but for alternate feeding periods of $12 \mathrm{~h}$ each, body-weight gains and NPU values were lower. These results suggested that the two protein sources, although provided at separate times, were nevertheless able to complement each other. Alternate feeding of $F$ and $S$ diets, for $6 \mathrm{~h}$ and for $12 \mathrm{~h}$, resulted in significantly better responses by the chickens than those obtained by the ad lib. feeding of either diet singly (treatments 2 and 3 ).

The treatments which included fasting periods represented a more rigorous separation of the two protein sources tested, and imposed additional constraints on food intake by reducing the daily feeding time. Over-all food intakes consequently decreased, as did body-weight gains, but the NPU values under these conditions (treatments 6 and 7) remained high. The results for this experiment indicated that good protein utilization for the diets when $F$ and $S$ were fed separately was not entirely dependent upon a mixing of the two diets in the digestive tract of the chicken but could still be satisfactory when the two diets were eaten at intervals separated by as much as $\mathrm{I} 2 \mathrm{~h}$. This phenomenon can be explained if it is assumed that a measure of temporary storage of amino acids can occur in the body of the growing chicken.

Food intake is known to affect $\mathrm{N}$ utilization (Calet, 1967 ) and food intake is also closely dependent upon both the energy content of the food and its protein value (Sibbald, Bowland, Berg \& Robblee, 1957; Summers, Slinger, Sibbald \& Pepper, 1964). Bender (1956) reported a positive correlation between food intake and protein efficiency ratio, and food intake and NPU. Miller \& Payne (196r, 1964a, $b$ ) have shown that when the food $\mathrm{N}$ content is fixed, $\mathrm{N}$ retention increases rapidly as a function of food energy content until a point at which energy becomes surplus to requirement when the balance increases very slowly. Calet (1967) suggested that, on this basis, restriction of food intake could affect $\mathrm{N}$ utilization. The restriction of food intake and, therefore, $\mathrm{N}$ intake in the present experiment had the effect of increasing the NPU for the combined diet (treatment groups 8 and 9 compared with treatment group I). The correlation coefficient for food intake $v$. NPU for these three treatments was -0.40 , which is significant $(P<0.05)$. This is in agreement with the work of De Muelenaere, Martin \& Murdoch (1965) who found that NPU increases at food protein contents up to $100 \mathrm{~g} / \mathrm{kg}$, and thereafter decreases.

The authors are indebted to Mrs Jean Lavers and the staff of the Poultry Section, Ukulinga, for assistance in the care of the experimental chickens. 


\section{REFERENCES}

Bender, A. E. (1956). Br. F. Nutr. 10, 135.

Bender, A. E. \& Doell, B. H. (1957). Br. F. Nutr. II, I38.

Calet, C. (1967). In Protein Utilization by Poultry [R. A. Morton and E. C. Amorosa, editors]. Edinburgh and London: Oliver \& Boyd.

De Muelenaere, H. J. H., Martin, R. S. \& Murdoch, M. G. (1965). F. Nutr. 85, 386.

Fisher, H. (1967). In Newer Methods of Nutritional Biochemistry, vol. 3 [A. A. Albanese, editor]. New York and London: Academic Press.

Geiger, E. (1947). f. Nutr. 34, 97.

Henderson, R. \& Harris, R. S. (I949). Fedn Proc. Fedn Am. Socs exp. Biol. 8, 382 Abstr.

Miller, D. S. \& Payne, P. R. (I96I).F. Nutr. 75, 225.

Miller, D. S. \& Payne, P. R. (1964a). Nature, Lond. 204, 480.

Miller, D. S. \& Payne, P. R. (1964b). Proc. Nutr. Soc. 23, I .

Saunders, A. J. (I974). An evaluation of sunflower oilcake meal and fishmeal as protein sources for chickens. MSc Thesis, University of Natal, South Africa.

Schaeffer, A. J. \& Geiger, E. (I947). Proc. Soc. exp. Biol. Med. 66, 309.

Sibbald, I. R., Bowland, J. P., Berg, R. T. \& Robblee, A. R. (1957). F. Nutr. 6z, I7I.

Summers, J. D., Slinger, S. J., Sibbald, I. R. \& Pepper, W. F. (r964). F. Nutr. 82, $46_{3}$.

Wessels, J. P. H. (1967). S. Afr. F. agric. Sci. xo, I1 3.

Yang, S. P., Clark, H. E. \& Vail, G. E. (196I). F. Nutr. 75, 241.

Yang, S. P., Steinhauer, J. E. \& Masterson, J. E. (I963). F. Nutr. 79, 257.

Yang, S. P., Tilton, K. S. \& Ryland, L. L. (I968). J. Nutr. 94, 178. 